\title{
Analisis Penyusunan dan Pelaksanaan Program Audit Laporan Keberlanjutan Perusahaan \\ (Studi pada Perusahaan dalam Industri Minyak dan Gas di Indonesia)
}

\author{
Putu Sukma Kurniawan ${ }^{1}$ \\ Jurusan Akuntansi Program S1, Fakultas Ekonomi, Universitas Pendidikan Ganesha \\ Jalan Udayana No. 11 Singaraja, Bali \\ putusukma1989@gmail.com
}

\begin{abstract}
This article aims to provide an understanding of the preparation and implementation of the audit program on the company's sustainability report. The audit on the sustainability report aims to provide confidence that the information presented in the sustainability report is correct and in accordance with GRI G4. Guidelines for the preparation and implementation of the audit program on sustainability reports are based on AA 1000 Assurance Standard (AA1000AS) and AA 1000 AccountAbility Principles (AA1000APS) guidelines. The object of research is the company's sustainability report, especially the sustainability report of companies engaged in the oil and gas industry. The research method uses descriptive methodology and literature review research design. The result of the research resulted a model of audit implementation on company sustainability report. The results of this study are expected to provide an understanding of the company's sustainability report audit and support the sustainability reporting process in Indonesia.
\end{abstract}

Keywords: audit; AA1000AS; AA1000APS; GRI G4; sustainability report; oil and gas industry

Abstrak. Artikel ini bertujuan untuk memberikan pemahaman mengenai penyusunan dan pelaksanaan program audit pada laporan keberlanjutan perusahaan. Audit pada laporan keberlanjutan bertujuan untuk memberikan keyakinan bahwa informasi yang disajikan dalam laporan keberlanjutan adalah benar dan sesuai dengan GRI G4. Pedoman dalam penyusunan dan pelaksanaan program audit atas laporan keberlanjutan didasarkan pada pedoman AA 1000 Assurance Standard (AA1000AS) dan AA 1000 AccountAbility Principles (AA1000APS). Objek penelitian adalah laporan keberlanjutan perusahaan, khususnya industri minyak dan gas. Metode penelitian mempergunakan metodologi deskriptif dan desain penelitian studi pustaka. Hasil penelitian menghasilkan sebuah model pelaksanaan audit pada laporan keberlanjutan perusahaan. Hasil penelitian ini diharapkan dapat memberikan pemahaman mengenai audit laporan keberlanjutan perusahaan dan mendukung proses pelaporan keberlanjutan di Indonesia.

Kata Kunci: audit; AA1000AS; AA1000APS; GRI G4; industri minyak dan gas; laporan keberlanjutan 


\section{PENDAHULUAN}

Laporan keberlanjutan perusahaan (sustainability report) kini menjadi bentuk pertanggungjawaban baru manajemen perusahaan. Manajemen perusahaan kini tidak lagi melaporkan sebatas angka-angka akuntansi saja kepada pemangku kepentingan perusahaan, namun informasi yang disampaikan kepada pemangku kepentingan perusahaan harus semakin komprehensif. Penyajian informasi-informasi non keuangan kini wajib disampaikan oleh manajemen perusahaan. Ballou, et al. (2006) menjelaskan bahwa tekanan dari pemangku kepentingan perusahaan (stakeholder) dapat memaksa manajemen perusahaan untuk memublikasikan tidak saja laporan keuangan namun juga informasi-informasi yang bersifat voluntary mengenai kinerja sosial dan lingkungan perusahaan. Manajemen perusahaan harus menyadari bahwa saat ini terdapat ekspektasi dari pemangku kepentingan perusahaan agar perusahaan dijalankan sesuai dengan prinsip-prinsip keberlanjutan. Naraduhita \& Sawarjuwono (2012) menyatakan bahwa dengan adanya peraturan yang mengatur mengenai tanggung jawab sosial dan lingkungan perusahaan (UU No. 40 Tahun 2007), maka pelaksanaan tanggung jawab sosial dan lingkungan merupakan sebuah keharusan bagi manajemen perusahaan.

Prinsip-prinsip keberlanjutan dalam aktivitas bisnis dapat diartikan bahwa bagaimana manajemen perusahaan menjalankan aktivitas bisnis perusahaan dengan turut pula memikirkan dampak yang ditimbulkan dari aktivitas bisnis tersebut, baik dampak sosial maupun dampak lingkungan. Prinsip keberlanjutan jika dijalankan dan dilaksanakan dengan baik oleh manajemen perusahaan diharapkan dapat meminimalkan dampak negatif sosial dan lingkungan yang diakibatkan oleh aktivitas bisnis perusahaan. Dalam konteks ini maka kita akan memahami bahwa tanggung jawab manajemen tidak hanya dilakukan kepada investor ataupun pemegang saham saja, namun lebih luas lagi kepada seluruh pemangku kepentingan perusahaan, yang dalam hal ini termasuk masyarakat yang ada di sekitar perusahaan. Laporan keberlanjutan yang disusun oleh manajemen perusahaan menjadi salah satu kunci bagi manajemen perusahaan untuk menjalin hubungan dengan seluruh pemangku kepentingan perusahaan. Laporan keberlanjutan dapat menjadi salah satu jawaban manajemen perusahaan jika ada pemangku kepentingan yang bertanya apakah aktivitas bisnis perusahaan telah dijalankan sesuai dengan prinsip-prinsip keberlanjutan. Lebih lanjut Lozano \& Huisingh (2011) menyatakan bahwa laporan keberlanjutan perusahaan yang disusun oleh manajemen tidak hanya bermanfaat untuk kepentingan internal perusahaan saja, namun juga bermanfaat untuk pengembangan pemangku kepentingan perusahaan secara berkelanjutan. Junior, et al. (2014) menjelaskan bahwa proses pelaporan keberlanjutan merupakan upaya manajemen perusahaan memberikan pertanggungjawaban atas pengelolaan perusahaan kepada pemangku kepentingan perusahaan.

Penyajian informasi dalam laporan keberlanjutan perusahaan menjadi penting ketika seluruh pemangku kepentingan perusahaan menggunakan informasi tersebut dalam pengambilan keputusan. Pemangku kepentingan perusahaan dapat mempergunakan informasi-informasi yang terdapat pada laporan keberlanjutan perusahaan tidak hanya untuk pengambilan keputusan bisnis, namun juga untuk pengambilan keputusan non bisnis. Guidry \& Patten (2010) menyelidiki mengenai reaksi pasar terhadap informasi dalam laporan keberlanjutan perusahaan saat laporan keberlanjutan perusahaan tersebut pertama kali dikeluarkan. Dalam penelitiannya, Guidry \& Patten (2010) turut pula untuk menilai perbedaan reaksi pasar yang dihubungkan dengan kualitas informasi dari laporan keberlanjutan perusahaan tersebut. Secara umum hasil penelitian Guidry \& Patten (2010) menunjukkan bahwa tidak terdapat reaksi yang signifikan pada pasar saat laporan keberlanjutan tersebut dikeluarkan oleh manajemen perusahaan, namun dapat disimpulkan bahwa perusahaan yang memiliki 
kualitas laporan yang baik mendapatkan reaksi yang positif dari pasar dibandingkan dengan perusahaan yang memiliki kualitas laporan yang rendah.

Penelitian Brown, et al. (2009) menghubungkan antara kualitas laporan keberlanjutan perusahaan dengan persepsi terhadap reputasi perusahaan. Hasil Brown, et al. (2009) menunjukkan bahwa kualitas dari laporan keberlanjutan perusahaan berhubungan positif dengan persepsi reputasi yang diterima oleh perusahaan. Hasil penelitian serupa dikemukakan oleh Ioannou \& Serafeim (2017) yang menemukan bahwa peningkatan transparansi informasi mengenai dampak aktivitas bisnis perusahaan terhadap komunitas sosial dan lingkungan sangat efektif untuk meningkatkan kualitas pengungkapan informasi yang secara langsung akan berpengaruh terhadap nilai perusahaan (dalam hal ini nilai perusahaan dicerminkan dalam nilai Tobin's Q). Hasil ini menjelaskan bahwa kualitas informasi yang disajikan dalam laporan keberlanjutan perusahaan dapat mempengaruhi pengambilan keputusan yang dilakukan oleh pemangku kepentingan perusahaan dan berpengaruh terhadap nilai perusahaan. Hasil penelitian Brown, et al. (2009) dan Ioannou \& Serafeim (2017) memberikan kita pemahaman bahwa pada dasarnya kualitas pengungkapan informasi dalam laporan keberlanjutan perusahaan dapat berpengaruh terhadap reputasi perusahaan dan nilai perusahaan.

Audit pada laporan keberlanjutan perusahaan menjadi hal yang krusial untuk memastikan bahwa informasi-informasi keuangan dan non keuangan yang disajikan pada laporan keberlanjutan adalah benar. Proses audit laporan keberlanjutan pada dasarnya bukan merupakan sebuah hal yang baru. Ini dibuktikan dengan adanya sebuah artikel dari Wallage (2000) yang membahas mengenai audit laporan keberlanjutan ditinjau dari sudut pandang auditor. Wallage (2000) berpendapat bahwa perlu dibuktikan pula asersi manajemen yang disampaikan pada laporan keberlanjutan dan auditor perlu melakukan sebuah prosedur verifikasi bahwa isi dari laporan keberlanjutan dapat dipertanggungjawabkan. Ballou, et al. (2006) berpendapat bahwa akuntan publik memainkan peran yang penting dalam memberikan pengukuran terhadap informasi sosial dan lingkungan perusahaan. Akuntan publik kini tidak hanya berfokus pada informasi-informasi keuangan perusahaan saja, namun tetap harus memerhatikan informasi sosial dan lingkungan perusahaan. Pendapat ini ditegaskan kembali oleh Basalamah \& Jermias (2005) yang berpendapat bahwa akuntan harus mengambil bagian dalam audit laporan sosial dan lingkungan yang dikeluarkan oleh manajemen perusahaan. Akuntan memiliki kemampuan audit yang akan membantu untuk memastikan kehandalan informasi yang disajikan di dalam laporan sosial dan lingkungan perusahaan.

Artikel ini mencoba untuk mengembangkan analisis penyusunan dan pelaksanaan program audit atas laporan keberlanjutan perusahaan. Penulis tertarik mengambil topik audit pada laporan keberlanjutan mengingat bahwa saat ini telah banyak perusahaan dalam berbagai industri yang telah melaporkan kinerja ekonomi, kinerja sosial, dan kinerja lingkungannya melalui laporan keberlanjutan. Beberapa alasan lain penulis mengambil topik audit pada laporan keberlanjutan perusahaan, yaitu audit laporan keberlanjutan merupakan salah satu infrastruktur pendukung pelaporan keberlanjutan perusahaan di Indonesia. Dengan adanya audit laporan keberlanjutan maka informasi yang disajikan dalam laporan keberlanjutan tersebut dapat dipergunakan oleh seluruh pemangku kepentingan perusahaan untuk pengambilan keputusan. Tentu saja audit laporan keberlanjutan ini merupakan salah satu infrastruktur pendukung dari pengembangan laporan keberlanjutan di Indonesia. Kurniawan (2017) berpendapat bahwa infrastruktur pendukung lain dari pelaporan keberlanjutan di Indonesia adalah adanya profesi Certified Sustainability Reporting Specialist (CSRS). Profesi CSRS merupakan profesi yang bertugas untuk menyusun laporan keberlanjutan perusahaan. Profesi CSRS memegang peranan yang penting untuk menerjemahkan kondisi aktual 
perusahaan ke dalam sebuah laporan keberlanjutan perusahaan Alasan berikutnya adalah audit laporan keberlanjutan memberikan kita sebuah pemahaman baru bahwa pada dasarnya kegiatan audit tidak terbatas pada audit laporan keuangan saja. Informasi-informasi yang bersifat non keuangan pun dapat diaudit sehingga kinerja perusahaan secara menyeluruh dapat dilihat dengan jelas. Ruang lingkup audit dalam konteks ini menjadi semakin luas dan memiliki dampak yang sangat besar terhadap perkembangan pelaporan perusahaan. Penulisan artikel ini diharapkan dapat memberikan pemahaman mengenai proses audit pada laporan keberlanjutan perusahaan. Penulis berharap pembahasan artikel ini dapat bermanfaat dalam proses pengembangan pelaporan keberlanjutan di Indonesia.

\section{KAJIAN LITERATUR}

Laporan keberlanjutan perusahaan merupakan bentuk evolusi pada proses pelaporan yang dilakukan oleh manajemen perusahaan. Laporan keberlanjutan merupakan sebuah laporan yang berisikan mengenai kinerja ekonomi, kinerja sosial, dan kinerja lingkungan perusahaan dengan didasarkan pada konsep triple bottom lines. Kolk (2004) menjelaskan bahwa sejak tahun 1989 tren perusahaan yang menyampaikan informasi non keuangan, khususnya mengenai sosial, lingkungan, dan kebijakan keberlanjutan, mengalami kenaikan yang signifikan. Dalam artikel Kolk (2004) pula kita dapat memahami bahwa terjadinya pengembangan dalam laporan keberlanjutan perusahaan khususnya pada hubungannya dengan aspek ekonomi dan dengan pemangku kepentingan perusahaan. Penelitian Hahn \& Kühnen (2013) membahas mengenai faktorfaktor yang berpengaruh terhadap proses pelaporan keberlanjutan perusahaan. Dalam penelitiannya Hahn \& Kühnen (2013) menyatakan bahwa masih terdapat beberapa hal yang belum mendukung pelaporan keberlanjutan perusahaan seperti belum adanya peraturan terkait pelaporan keberlanjutan perusahaan, belum adanya prinsip dalam tata kelola perusahaan yang mendukung proses pelaporan keberlanjutan perusahaan, dan persepsi pemangku kepentingan yang berbeda terhadap laporan keberlanjutan perusahaan. Dalam konteks laporan keberlanjutan kita dapat memahami bahwa alasan manajemen perusahaan mengeluarkan informasi sosial dan lingkungan adalah adanya tekanan pemangku kepentingan kepada manajemen perusahaan untuk melaporkan informasi sosial dan lingkungan serta dampak aktivitas bisnis perusahaan. Hasil penelitian yang menarik dikemukakan oleh Basalamah \& Jermias (2005) yang menemukan bahwa manajemen perusahaan melakukan pelaporan informasi sosial dan lingkungan dikarenakan adanya alasan strategis bagi bisnis perusahaan dan bukan didasarkan pada tanggung jawab sosial yang dirasakan manajemen perusahaan. Hal ini dibuktikan oleh Basalamah \& Jermias (2005) yang menemukan bahwa manajemen perusahaan akan melaporkan kegiatan sosial dan lingkungan jika terdapat "ancaman" terhadap legitimasi perusahaan dan aktivitas bisnis perusahaan. Berdasarkan fakta ini kita dapat memahami bahwa penyajian informasi sosial dan lingkungan dapat menjadi strategi defensif atau strategi bertahan bagi manajemen perusahaan agar legitimasi perusahaan dalam menjalankan aktivitas bisnisnya tetap bertahan. Hal ini tentu saja berbanding terbalik dengan beberapa teori yang menyatakan bahwa manajemen perusahaan mengeluarkan informasi sosial dan lingkungan untuk menjalin komunikasi yang baik dengan seluruh pemangku kepentingan perusahaan. Apapun alasan dan motif manajemen perusahaan dalam mengeluarkan laporan keberlanjutan, laporan keberlanjutan dapat menjadi sebuah alat bagi seluruh pemangku kepentingan perusahaan untuk dapat menilai kinerja perusahaan secara komprehensif. Perkembangan mengenai proses pelaporan keberlanjutan perusahaan pada negara-negara berkembang diteliti oleh Amran \& Haniffa (2011). Dalam hasil penelitiannya Amran \& Haniffa (2011) menyatakan bahwa saat ini sudah semakin banyak manajemen perusahaan yang berinisiatif untuk menyajikan informasi non 
keuangan melalui laporan keberlanjutan dan untuk negara berkembang perusahaanperusahaan yang tergabung dalam industri pertanian dan perkebunan memiliki tingkat pelaporan keberlanjutan yang cukup signifikan. Pengembangan berikutnya dari pelaporan keberlanjutan adalah adanya konsep pelaporan terintegrasi (integrated reporting) dimana laporan terintegrasi merupakan laporan yang menyajikan informasi yang komprehensif mengenai nilai ekonomi, nilai sosial, dan nilai lingkungan yang diciptakan perusahaan kepada seluruh pemangku kepentingan perusahaan. Setiawan (2016) menyatakan bahwa perusahaanperusahaan yang memenangkan Indonesia Sustainability Reporting Award telah siap untuk menyajikan pelaporan terintegrasi. Pelaporan terintegrasi ini menjadi penting sehingga pemangku kepentingan perusahaan dapat menilai perusahaan dengan lebih komprehensif dan objektif tidak hanya dari sisi finansial namun juga dari sisi non finansial.

Audit pada laporan dapat diartikan sebagai sebuah proses untuk memastikan bahwa informasi yang disajikan dalam laporan tersebut telah disusun sesuai dengan aturan dan ketentuan yang berlaku. Wallage (2000) berpendapat bahwa auditor dalam melakukan audit laporan keberlanjutan harus mampu membuktikan asersi manajemen dan melakukan sebuah verifikasi terhadap informasi yang disajikan di dalam laporan keberlanjutan perusahaan. Ballou, et al. (2006) menjelaskan bahwa auditor pun memiliki peran yang penting dalam pelaporan keberlanjutan dimana auditor bertugas untuk memastikan bahwa sistem dan praktek yang berlangsung di perusahaan tersebut telah sesuai dengan prinsip-prinsip keberlanjutan. Audit pada laporan keberlanjutan (sustainability assurance) bertujuan untuk memberikan pandangan yang komprehensif dalam pengelolaan perusahaan yang berfokus pada manajemen, kinerja, dan pelaporan perusahaan dalam konteks keberlanjutan. Beberapa tujuan khusus dari audit laporan keberlanjutan perusahaan, yaitu (1) untuk melakukan evaluasi bagaimana organisasi menentukan isu-isu keberlanjutan yang sesuai dengan aktivitas bisnis perusahaan, (2) untuk melihat bagaimana respon manajemen perusahaan terhadap isu-isu keberlanjutan dalam aktivitas bisnis perusahaan, dan (3) untuk melakukan evaluasi terhadap reliabilitas informasi keberlanjutan yang disampaikan oleh manajemen perusahaan. Audit laporan keberlanjutan tidak hanya bertujuan untuk melakukan evaluasi pada informasi keberlanjutan yang disampaikan oleh manajemen perusahaan saja, namun juga dapat bermanfaat untuk proses internal perusahaan. Manfaat audit laporan keberlanjutan perusahaan bagi proses bisnis internal perusahaan, yaitu (1) untuk meningkatkan kinerja keberlanjutan perusahaan dan (2) untuk mengevaluasi aktivitas bisnis perusahaan yang dihubungkan dengan dampak yang dihasilkan dari aktivitas bisnis tersebut. Kinerja keberlanjutan perusahaan dalam konteks ini adalah kinerja ekonomi, kinerja sosial, dan kinerja lingkungan (triple bottom lines). Peningkatan kinerja keberlanjutan perusahaan dapat dipahami sebagai tidak hanya peningkatan kinerja ekonomi perusahaan saja, tetapi diiringi juga dengan peningkatan kinerja sosial perusahaan dan kinerja lingkungan perusahaan. Pendapat juga disampaikan oleh Basalamah \& Jermias (2005) yang menyatakan bahwa audit laporan sosial dan lingkungan perusahaan memerlukan kompetensi akuntan karena dalam konteks ini akuntan memiliki kemampuan untuk melakukan pemeriksaan terhadap kualitas informasi sosial dan lingkungan perusahaan.

Penulisan artikel ini didasarkan pada beberapa penelitian terdahulu. Morimoto, et al. (2005) mengembangkan sebuah sistem audit untuk melakukan audit pada corporate social responsibility perusahaan. Penelitian Morimoto, et al. (2005) berusaha untuk mengembangkan sebuah kerangka kerja dalam melakukan audit terhadap tanggung jawab sosial perusahaan. Manetti \& Becatti (2009) membahas mengenai jasa audit terhadap laporan keberlanjutan perusahaan dan membahas mengenai standar audit yang dapat dipergunakan secara internasional. 
Manetti \& Becatti (2009) pada artikelnya mempergunakan pedoman berbasis pada GRI 2006. Mock, et al. (2007) meneliti mengenai proses audit laporan keberlanjutan pada 130 perusahaan di seluruh dunia dan menghubungkannya dengan tipe assurance provider yang melakukan audit, apakah assurance provider tersebut masuk ke Big 4 ataukah ke Non Big 4. Srivastava, et al. (2013) mengembangkan sebuah kerangka kerja untuk perencanaan, pelaksanaan, dan evaluasi bukti dalam melakukan jasa audit terhadap laporan keberlanjutan perusahaan. Kerangka kerja yang disusun oleh Srivastava, et al. (2013) disesuaikan dengan kerangka kerja pelaporan GRI G3. Hasil penelitian Srivastava, et al. (2013) dapat dijadikan pedoman audit laporan keberlanjutan perusahaan, jika manajemen perusahaan menyusun laporan keberlanjutannya menggunakan standar pelaporan GRI G3. Dalam perkembangannya standar GRI G3 dikembangkan menjadi standar GRI G4 dan selanjutnya standar GRI G4 dikembangkan menjadi GRI Standards.

\section{METODOLOGI PENELITIAN}

Metodologi penelitian yang dipergunakan dalam artikel ini adalah metodologi penelitian deskriptif. Metode penelitian deskriptif merupakan metode penelitian yang bertujuan untuk menghasilkan penjelasan atau deskripsi terkait dengan fenomena atau topik penelitian yang sedang diteliti. Metode penelitian deskriptif tidak dipergunakan untuk pengujian hipotesis, tetapi lebih kepada penggambaran suatu objek sehingga dapat dianalisis dengan lebih mendalam. Untuk membantu dalam penyusunan analisis, maka dipergunakan juga metode penelitian studi pustaka atau studi literatur. Studi pustaka dipergunakan untuk mencari pustaka atau literatur yang relevan dengan topik penelitian dan mempergunakannya untuk mendukung analisis yang akan dibuat. Tujuan dari studi pustaka atau studi literatur adalah untuk mengumpulkan data dan informasi yang berasal dari berbagai pustaka dan dipergunakan untuk mengembangkan argumentasi terkait topik penelitian.
Beberapa artikel yang menjadi pedoman dan rujukan dalam penulisan artikel ini adalah Morimoto, et al. (2005), Mock, et al. (2007), dan Srivastava, et al. (2013). Untuk menyusun pengembangan model program audit maka penelitian ini menggunakan satu contoh laporan keberlanjutan perusahaan yang belum diaudit oleh pihak eksternal, yaitu laporan keberlanjutan PT. Pertamina EP Cepu tahun 2015. Diasumsikan bahwa dalam penelitian ini akan dilakukan audit terhadap laporan keberlanjutan PT. Pertamina EP Cepu tahun 2015. Penelitian ini menggunakan laporan keberlanjutan PT. Pertamina EP Cepu tahun 2015 dengan beberapa alasan, yaitu (1) PT. Pertamina EP Cepu termasuk perusahaan yang tergabung dalam industri minyak dan gas (oil and gas industry) sehingga aktivitas dan operasional bisnisnya memiliki dampak pada unsur sosial dan lingkungan di sekitar perusahaan, (2) Dengan adanya dampak sosial dan lingkungan, maka manajemen perusahaan akan mencoba untuk menyajikan item-item informasi pada laporan keberlanjutan perusahaan yang sesuai dengan pedoman GRI G4, dan (3) PT. Pertamina EP Cepu merupakan salah satu perusahaan yang mengikuti Sustainability Reporting Award sehingga penggunaan laporan keberlanjutan PT. Pertamina EP Cepu akan membuat penelitian ini menjadi objektif. Standar atau pedoman audit yang dipergunakan dalam penelitian ini adalah standar AA 1000 Assurance Standard (AA1000AS). Standar atau pedoman audit AA1000AS dikeluarkan oleh AccountAbility yang berpusat di Inggris pada bulan Maret 2003. Standar AA1000AS merupakan standar internasional yang dipergunakan untuk kegiatan assurance pada ruang lingkup keberlanjutan perusahaan. Untuk melakukan penilaian terhadap prinsipprinsip keberlanjutan perusahaan, maka dalam penelitian ini didasarkan pada standar AA 1000 AccountAbility Principles (AA1000APS). Standar AA1000APS merupakan sebuah standar untuk menilai prinsip keberlanjutan perusahaan yang terdiri dari prinsip inklusivitas, prinsip materialitas, dan prinsip responsivitas. 


\section{HASIL DAN PEMBAHASAN}

Dalam penyusunan artikel ini objek dari laporan keberlanjutan yang diaudit adalah laporan keberlanjutan PT. Pertamina EP Cepu tahun 2015. Pada laporan keberlanjutan PT. Pertamina EP Cepu tahun 2015, pada halaman 15, dinyatakan bahwa laporan keberlanjutan PT. Pertamina EP Cepu tahun 2015 belum mendapatkan penjaminan (audit) dari pihak eksternal perusahaan. Dengan kata lain laporan keberlanjutan PT. Pertamina EP Cepu tahun 2015 belum diaudit. Dalam artikel ini akan dicoba untuk membuat sebuah model penyusunan dan pelaksanaan program audit untuk audit atau pemeriksaan mengenai laporan keberlanjutan PT. Pertamina EP Cepu tahun 2015.

Dalam bagian hasil pembahasan artikel ini secara umum terbagi menjadi tiga tahapan. Tiga tahapan tersebut merupakan tahapantahapan dalam melakukan penyusunan dan pelaksanaan program audit laporan keberlanjutan perusahaan. National Center for Sustainability Reporting (2017) menjelaskan bahwa pada audit laporan keberlanjutan setidaknya terdapat tahapan mengenai penerimaan perikatan audit (accepting an engagement), perencanaan audit, dan pelaporan hasil audit. Model audit pada penelitian ini merujuk pada tahapan yang diberikan oleh National Centre for Sustainability Reporting. Tiga tahapan model audit dalam penelitian ini, yaitu penyusunan engagement angreement, penyusunan dan pelaksanaan assurance program, dan penyusunan independence assurance statement.

Penyusunan engagement agreement atau kontrak penugasan audit merupakan tahapan yang pertama. Dalam bagian ini dilakukan penyusunan kontrak penugasan audit yang mencakup beberapa item-item informasi seperti standar audit yang dipergunakan, tipe dan level audit, susunan atau komposisi tim audit, jangka waktu audit, dan rencana anggaran untuk melakukan audit. Dalam kontrak penugasan audit ini sangat penting untuk mengetahui komposisi tim yang akan melakukan audit. Ini dikarenakan bahwa kompetensi tim audit akan menentukan kualitas audit nantinya. Kompetensi tim audit dibagi menjadi dua, yaitu kompetensi umum dan kompetensi spesifik. Kompetensi umum mencakup pemahaman pada standar-standar audit, pemahaman pada praktek-praktek audit, dan pemahaman mengenai kepentingan stakeholder perusahaan. Kompetensi khusus mencakup pemahaman yang spesifik pada bidang ekonomi, sosial, dan lingkungan. Hal yang paling penting juga dalan kontrak penugasan audit adalah ketentuan jangka waktu pelaksanaan audit. Dalam konteks ini jangka waktu pelaksanaan audit telah mencakup mulai dari perencanaan, pelaksanaan, sampai tahap penyusunan laporan audit atau penyusunan independence assurance statement. Dalam kontrak penugasan audit juga harus terdapat item kewajiban yang harus dilaksanakan oleh perusahaan yang diaudit dan assurance provider. Konsultan atau perusahaan yang melakukan audit dalam laporan keberlanjutan perusahaan diistilahkan dengan assurance provider. Seperti disebutkan dalam artikel Mock, et al. (2007), assurance provider dapat masuk ke dalam kategori Big 4 ataupun Non Big 4. Tidak dapat dipungkiri bahwa salah satu faktor yang menentukan kualitas audit adalah kompetensi dan pengalaman dari assurance provider. Hasil penelitian Perego (2009) menjelaskan bahwa assurance provider kategori Big 4 memiliki kualitas yang lebih baik dalam hal format pelaporan dan prosedur audit. Dalam kontrak penugasan audit juga harus dicantumkan mengenai rencana anggaran biaya yang akan dipergunakan dalam kegiatan audit laporan keberlanjutan PT. Pertamina EP Cepu tahun 2015. Secara umum item-item yang terdapat dalam kontrak penugasan audit harus ringkas dan jelas serta mengakomodir semua kepentingan. Dalam artikel ini diasumsikan pihak yang menjadi assurance provider (pihak auditor) adalah SK Consultant. Berdasarkan rencana kontrak penugasan audit, maka asumsi dalam penelitian ini, yaitu SK Consultant (assurance provider) melakukan audit terhadap laporan keberlanjutan PT. Pertamina EP Cepu untuk tahun 2015. 
Penyusunan dan pelaksanaan assurance program merupakan tahapan yang kedua. Penyusunan assurance program merupakan penyusunan program-program kerja saat melakukan audit laporan keberlanjutan PT. Pertamina EP Cepu tahun 2015. Dalam assurance program akan ditentukan bagaimana teknis pelaksanaan audit sehingga nantinya audit yang dilakukan terhadap isi laporan keberlanjutan dapat dipertanggungjawabkan dengan baik. Penyusunan assurance program didasarkan pada pedoman standar AA1000AS yang telah umum dipergunakan sebagai standar dalam audit laporan keberlanjutan. Dalam penulisan artikel ini diasumsikan bahwa program audit masuk dalam tipe 2 dan level moderat. Berdasarkan standar AA1000AS terdapat dua tipe dan dua level dari audit laporan keberlanjutan. Dua tipe tersebut, yaitu tipe 1 (audit yang hanya memeriksa prinsip-prinsip keberlanjutan dalam aktivitas bisnis perusahan) dan tipe 2 (audit yang memeriksa prinsip-prinsip keberlanjutan perusahaan dan kualitas informasi yang disampaikan di dalam laporan keberlanjutan perusahaan). Dua level dalam audit laporan keberlanjutan, yaitu high level (cakupan audit lebih luas) dan moderate level (cakupan audit menengah).

Penyusunan independence assurance statement merupakan tahapan yang terakhir. Dalam penyusunan independence assurance statement harus dilakukan identifikasi informasi minimum yang harus disertakan dalam pernyataan assurance untuk klien yang sesuai dengan AA 1000AS. Dalam konteks ini maka assurance provider harus mampu menentukan dan mengidentifikasi informasi minimum yang harus dicantumkan di dalam independence assurance statement. Informasi minimum ini nantinya harus mampu meyakinkan pemangku kepentingan perusahaan bahwa perusahaan dalam menyusun laporan keberlanjutannya telah sesuai dengan prinsip-prinsip pelaporan keberlanjutan dan standar dalam penyusunan laporan keberlanjutan. Sesuai dengan ketentuan dalam standar AA1000AS terdapat beberapa informasi minimum yang harus dicantumkan dalam independence assurance statement. Penyusunan independence assurance statement disesuaikan dengan informasi-informasi yang disajikan di dalam laporan keberlanjutan PT. Pertamina EP Cepu tahun 2015.

Tahap pertama dalam penyusunan engagement agreement adalah menentukan komposisi tim yang akan melakukan audit laporan keberlanjutan PT. Pertamina EP Cepu tahun 2015. Pada tahap penyusuan engagement agreement ini terdapat beberapa hal yang harus diperhatikan terkait dengan tim audit, yaitu (1) komposisi dari tim audit, (2) kompetensi setiap anggota tim audit, (3) peran dan kewajiban dari setiap anggota tim audit, dan (4) kode etik tim audit. Secara umum tim audit terdiri dari engagement leader (penanggung jawab), engagement manager (ketua tim audit), dan multidisciplinary team (anggota yang berasal dari multidisiplin). Tim multidisiplin dalam tim audit ini dapat terdiri dari ahli profesional yang mendalami isu-isu ekonomi, sosial, dan lingkungan yang berfokus pada industri pertambangan. Dalam konteks ini maka tenaga professional yang diperlukan harus mendalami materi mengenai limbah industri pertambangan, dampak lingkungan akibat dari bisnis PT. Pertamina EP Cepu, kesehatan dan keselamatan kerja pada industri pertambangan, dan dampak sosial akibat kegiatan operasional PT. Pertamina EP Cepu. Dalam melaksanakan audit laporan keberlanjutan perusahaan, setiap anggota tim audit memiliki kode etik yang harus dilaksanakan saat melakukan audit. Beberapa kode etik yang harus dimiliki oleh setiap anggota tim audit adalah (1) integritas dan objektifitas, (2) menghindari konflik kepentingan, (3) memiliki kompetensi yang professional, (4) dan independensi. Dalam konteks ini harus dipastikan bahwa setiap anggota dari tim audit tidak memiliki konflik kepentingan dengan perusahaan yang akan diaudit. Independensi dari setiap anggota tim audit sangat penting untuk menghasilkan proses audit laporan keberlanjutan perusahaan yang baik. Tahap berikutnya dalam penyusunan engagement agreement adalah menentukan ruang lingkup dari audit laporan keberlanjutan (scope of the engagement). 
Dalam menentukan ruang lingkup dari audit laporan keberlanjutan terdapat beberapa hal yang harus diperhatikan, yaitu (1) disclosures covered (hal-hal apa saja yang akan diperiksa dalam audit), (2) suitable citeria (kriteria atau ketentuan audit yang akan dipergunakan), (3) level of assurance (tingkat dan level audit yang akan dipergunakan). Penentuan ruang lingkup dalam audit laporan keberlanjutan ini sangat penting untuk menentukan program kerja audit yang nanti akan dilaksanakan di lapangan.

Pada proses audit laporan keberlanjutan PT. Pertamina EP Cepu tahun 2015 direncanakan menggunakan rencana anggaran biaya untuk memperlancar proses audit laporan keberlanjutan. Dalam rencana anggaran biaya ini dibagi menjadi tiga bagian umum, yaitu (1) honor tim yang mencakup honor bagi engagement leader, reviewing authority, engagement manager, dan tim ahli di bidang ekonomi, sosial, dan lingkungan, (2) anggaran yang mencakup akomodasi, transportasi, dan komunikasi, dan (3) anggaran untuk melakukan focus group discussion dengan stakeholders perusahaan dan manajemen perusahaan. Segala bentuk rencana anggaran biaya ini telah disesuaikan dengan rencana kegiatan audit sehingga diharapkan kegiatan audit laporan keberlanjutan perusahaan dapat berjalan dengan maksimal. Rencana anggaran biaya harus disusun berdasarkan prioritas kegiatan dan didasarkan pada pertanggungjawaban yang logis.

Penyusunan dan pelaksanaan assurance program merupakan penyusunan programprogram kerja yang akan dilaksanakan ketika akan melakukan audit laporan keberlanjutan PT. Pertamina EP Cepu tahun 2015. Penyusunan assurance program didasarkan pada tipe dan level dari audit dimana dalam konteks ini adalah tipe 2 dengan level moderat. Dalam pemeriksaan tipe 2, assurance program atau audit harus melakukan pemeriksaan terhadap seluruh aspek pada prinsip pelaporan keberlanjutan perusahaan. Ruang lingkup yang harus dicapai dalam assurance program harus mampu untuk menunjukkan bahwa (1) prinsip dalam laporan keberlanjutan PT. Pertamina EP Cepu tahun 2015 telah sesuai dengan standar AA1000APS (atau dengan kata lain prinsip laporan keberlanjutan perusahaan telah sesuai dengan prinsip inklusivitas, prinsip materialitas, dan prinsip responsivitas) dan (2) kualitas informasi yang spesifik dalam laporan keberlanjutan harus sesuai dengan standar dalam pelaporan keberlanjutan. Teknik pengumpulan data yang dilakukan dalam audit ini adalah observasi lapangan dan analisis dokumen perusahaan yang berkaitan dengan proses penyusunan laporan keberlanjutan perusahaan. Pengumpulan data dapat juga dilakukan dengan melakukan interview atau wawancara kepada manajemen perusahaan dan pemangku kepentingan perusahaan. Konsep assurance program yang disusun harus sesuai dengan ruang lingkup audit yang telah disepakati. Salah satu dasar atau pertimbangan untuk menentukan assurance program adalah ukuran perusahaan dan kompleksitas bisnis perusahaan. Penyusunan assurance program akan banyak jika ukuran perusahaan besar dan perusahaan memiliki kompleksitas bisnis yang tinggi.

Langkah-langkah dalam assurance program yang direncanakan untuk audit laporan keberlanjutan PT. Pertamina EP Cepu tahun 2015, yaitu (1) penentuan tingkat materialitas informasi laporan keberlanjutan, (2) observasi lapangan, (3) pengumpulan bukti-bukti audit, (4) diskusi kelompok terpumpun dengan stakeholders dan manajemen, dan (5) penyusunan rekomendasi bagi manajemen perusahaan.

Penentuan tingkat materialitas informasi laporan keberlanjutan merupakan langkah pertama dalam assurance program. Penentuan tingkat materialitas dapat diartikan sebagai tahapan untuk menentukan informasiinformasi mana saja yang bersifat material dalam laporan keberlanjutan perusahaan. Informasi yang material dapat dipahami sebagai informasi yang penting yang disampaikan manajemen perusahaan kepada pemangku kepentingan perusahaan dan memiliki dampak yang luas bagi pemangku kepentingan perusahaan. Khusus untuk laporan keberlanjutan PT. Pertamina EP Cepu 
penentuan tingkat materialitas informasi dilihat dari ruang lingkup aktivitas bisnis perusahaan dan melakukan penilaian terhadap dampak aktivitas bisnis perusahaan terhadap seluruh pemangku kepentingan perusahaan. Beberapa informasi yang bersifat material dalam ruang lingkup aktivitas bisnis PT. Pertamina EP Cepu adalah informasi mengenai kinerja keuangan perusahaan, pengelolaan limbah perusahaan, kesejahteraan karyawan, dan kontribusi manajemen perusahaan kepada lingkungan sosial di sekitar perusahaan. Penentuan tingkat materialitas informasi ini dapat didasarkan pada jenis industri dari perusahaan yang akan diaudit. PT. Pertamina EP Cepu bergerak dalam industri minyak dan gas yang aktivitas bisnisnya dapat berpengaruh ke komunitas sosial dan lingkungan sekitar. Hal ini akan menyebabkan informasi mengenai kinerja sosial dan kinerja lingkungan PT. Pertamina EP Cepu akan bersifat material. Hasil penelitian Burhan \& Rahmanti (2012) menyatakan bahwa kinerja sosial perusahaan sangat berpengaruh terhadap kinerja perusahaan secara umum. Dengan hal ini kita dapat memahami bahwa informasi-informasi, khususnya informasi kinerja sosial perusahaan, dapat berpengaruh terhadap kinerja perusahaan keseluruhan. Dalam penentuan tingkat materialitas informasi ini juga dihubungkan dengan inklusivitas, materialitas, dan responsivitas manajemen perusahaan pada prinsip-prinsip laporan keberlanjutan perusahaan.

Langkah berikutnya dalam assurance program adalah melakukan observasi secara langsung ke lapangan, yaitu ke lokasi PT. Pertamina EP Cepu. Observasi ini penting untuk membandingkan informasi yang terdapat dalam laporan keberlanjutan perusahaan dengan fakta sebenarnya di lapangan. Hal-hal yang diobservasi adalah informasi-informasi yang bersifat material bagi manajemen perusahaan. Observasi yang dilakukan dapat juga mencakup mengenai kegiatan operasional perusahaan. Tim audit dalam observasi ke lapangan ini dapat juga melakukan observasi pada sistem, proses, dan data yang dipergunakan oleh manajemen PT.
Pertamina EP Cepu untuk mendukung pengungkapan kinerja keberlanjutan perusahaan yang telah disampaikan pada laporan keberlanjutan perusahaan.

Tahap berikutnya dalam assurance program adalah pengumpulan bukti-bukti audit. Bukti-bukti audit ini dapat berupa dokumen-dokumen yang terkait dengan aktivitas bisnis perusahaan. Pengumpulan bukti-bukti audit dapat dilakukan dengan melakukan analisis dokumen-dokumen perusahaan yang berhubungan dengan prinsip-prinsip keberlanjutan perusahaan. Pengumpulan bukti audit sangat penting untuk mendukung independent assurance statement yang nantinya akan dikeluarkan oleh assurance provider. Sebagai contoh misalkan tim ahli dalam bidang lingkungan ingin mengetahui bagaimana kebijakan manajemen perusahaan dalam pengelolaan limbah, maka bukti audit yang dicari adalah dokumen mengenai prosedur pengelolaan limbah dalam lingkungan perusahaan. Hal ini tentu akan mendukung independent assurance statement sehingga independent assurance statement dapat memberikan keyakinan bagi seluruh pemangku kepentingan perusahaan. Dalam melakukan pengumpulan bukti-bukti audit, hal yang penting adalah menentukan metode sampel untuk menentukan bukti-bukti yang akan dipergunakan. Sampel bukti yang dipergunakan harus mampu meyakinkan auditor bahwa bukti tersebut telah cukup untuk mewakili semua informasi yang diperlukan oleh auditor. Semakin tinggi level audit yang digunakan, maka semakin banyak bukti yang dikumpulkan auditor untuk memastikan bahwa prinsip-prinsip laporan keberlanjutan perusahaan telah sesuai dengan standar AA1000APS dan penyusunan laporan keberlanjutan telah sesuai dengan standar GRI G4 (Global Reporting Initiative Generasi Keempat). Dalam konteks penelitian ini, maka auditor harus mampu untuk mengumpulkan bukti-bukti audit agar yakin bahwa informasi yang disajikan di laporan keberlanjutan PT. Pertamina EP Cepu adalah benar dan sesuai dengan fakta di lapangan.

Diskusi kelompok terpumpun dengan stakeholders (pemangku kepentingan 
perusahaan) dan manajemen perusahaan merupakan tahapan yang keempat dalam assurance program. Diskusi dengan pemangku kepentingan perusahaan dan manajemen perusahaan akan memberikan pemahaman baru bagi tim audit mengenai prinsip-prinsip keberlanjutan perusahaan. Kegiatan diskusi ini juga sebagai sarana bagi tim audit untuk melakukan konfirmasi terhadap informasi-informasi yang disajikan oleh manajemen perusahaan dalam laporan keberlanjutan perusahaan. Konfirmasi ini sangat penting untuk menghubungkan antara hasil observasi lapangan dan bukti audit yang telah dikumpulkan dengan konfirmasi pemangku kepentingan dan manajemen perusahaan. Jika hasil konfirmasi sesuai dengan hasil observasi dan pengumpulan bukti audit, maka pengambilan kesimpulan mengenai prinsip-prinsip keberlanjutan perusahaan akan semakin dapat dipertanggungjawabkan. Dalam konteks audit laporan keberlanjutan PT. Pertamina EP Cepu tahun 2015, tim audit dapat melakukan diskusi kelompok terpumpun dengan pemangku kepentingan yang terkait dengan bisnis perusahaan atau pemangku kepentingan yang terkena dampak dari aktivitas bisnis perusahaan. Tim audit harus dapat melakukan identifikasi mengenai siapa saja kelompok pemangku kepentingan perusahaan. Penentuan dari kelompok pemangku kepentingan perusahaan salah satunya dapat didasarkan pada kelompok yang berhubungan dengan aktivitas bisnis perusahaan atau kelompok yang dapat terkena dampak positif dan negatif dari aktivitas bisnis perusahaan. Latar belakang dari diadakannya diskusi kelompok terpumpun dengan seluruh pemangku kepentingan perusahaan didasarkan pada hasil penelitian O'Dwyer \& Owen (2005) yang menunjukan bahwa tidak adanya partisipasi pemangku kepentingan perusahaan dalam proses penjaminan laporan keberlanjutan perusahaan. Bradford, et al. (2016) dalam hasil penelitiannya mengungkapkan bahwa masih terdapat kesenjangan informasi antara apa yang diungkapkan oleh manajemen dalam laporan keberlanjutan dengan informasi apa yang diharapkan oleh pemangku kepentingan perusahaan. Adanya diskusi kelompok terpumpun ini dimaksudkan untuk memunculkan keterlibatan pemangku kepentingan perusahaan (meskipun keterlibatan secara tidak langsung) dalam proses audit laporan keberlanjutan perusahaan. Dewasa ini telah banyak manajemen perusahaan yang menggunakan media sosial untuk membantu menjalin hubungan dengan pemangku kepentingan. Penelitian Manetti \& Bellucci (2016) menunjukkan bahwa manajemen perusahaan menggunakan media sosial untuk menjalin hubungan dengan pemangku kepentingan dalam konteks keberlanjutan.

Tahap terakhir dari assurance program adalah melakukan penyusunan rekomendasi bagi manajemen perusahaan. Rekomendasi ini disusun berdasarkan hasil audit yang telah diperoleh. Tujuan dari penyusunan rekomendasi ini adalah untuk memberikan saran dan penjelasan bagi manajemen perusahaan dalam upaya untuk meningkatkan kualitas laporan keberlanjutan perusahaan pada tahun berikutnya. Rekomendasi bagi manajemen perusahaan disusun berdasarkan kekurangan-kekurangan yang terdapat dalam laporan keberlanjutan perusahaan. Saran atau rekomendasi yang diberikan dapat dipergunakan oleh manajemen perusahaan dalam melakukan perbaikan yang terkait dengan prinsip-prinsip keberlanjutan dalam aktivitas bisnis perusahaan. Sesuai ketentuan dalam kontrak penugasan, maka manajemen perusahaan wajib untuk melakukan rekomendasi yang telah diberikan oleh assurance provider. Diharapkan dengan rekomendasi yang telah disusun, manajemen perusahaan dapat melakukan perbaikan bagi laporan keberlanjutan perusahaan di tahun berikutnya. Dalam tahapan ini dapat pula dilakukan analisis resiko jika manajemen perusahaan tidak melakukan prinsip-prinsip keberlanjutan yang telah disarankan oleh tim auditor.

Dalam penyusunan independent assurance statement (pernyataan auditor mengenai isi laporan keberlanjutan perusahaan) harus diidentifikasi informasi 
minimum yang nantinya harus dimasukkan ke dalam pernyataan assurance provider terkait dengan isi laporan keberlanjutan PT. Pertamina EP Cepu tahun 2015. Independent assurance statement merupakan pernyataan assurance provider mengenai isi dari laporan keberlanjutan perusahaan yang diaudit. Pernyataan tersebut merupakan pernyataan yang independen dan dapat dipertanggungjawabkan. Beberapa informasi yang harus dicantumkan di dalam independent assurance statement, yaitu

1. Intended users of the assurance statement

Informasi pertama yang harus dicantumkan dalam independent assurance statement adalah ditujukan kepada siapa independent assurance statement tersebut. Dalam hal ini maka independent assurance statement ditujukan kepada manajemen PT. Pertamina EP Cepu. Umumnya independent assurance statement ditujukan kepada manajemen perusahaan yang diaudit.

2. The responsibility of the reporting organisation and of the assurance provider

Informasi berikutnya yang harus ada di dalam independent assurance statement adalah kewajiban dari perusahaan yang diaudit (PT. Pertamina EP Cepu) dan kewajiban dari assurance provider (auditor).

3. Assurance standard/s used, including reference to the AA1000AS (2008)

Informasi berikutnya yang harus ada adalah standar audit yang dipergunakan. Dalam pelaksanaan audit ini diasumsikan menggunakan standar audit AA1000AS. Secara umum standar audit yang dipergunakan dalam audit laporan keberlanjutan perusahaan adalah standar audit AA1000AS.

4. Description of the scope, including the type of assurance provided

Dalam independent assurance statement harus dicantumkan ruang lingkup, termasuk dengan tipe dan level dari audit yang telah dilaksanakan.
Penentuan ruang lingkup, tipe, dan level audit harus ditentukan sebelum melaksanakan kegiatan audit dan merupakan kesepakatan antara perusahaan yang diaudit dengan assurance provider.

5. Description of disclosures covered Informasi berikutnya adalah deskripsi dari ruang lingkup pengungkapan dalam laporan keberlanjutan perusahaan.

6. Description of methodology

Informasi yang juga harus dicantumkan dalam independent assurance independent adalah teknik atau metodologi yang dipergunakan oleh assurance provider dalam melaksanakan kegiatan audit.

7. Any limitations

Assurance provider harus mengungkapkan mengenai keterbatasan-keterbatasan yang dihadapi saat melaksanakan kegiatan audit. Dapat juga dijelaskan bagaimana cara assurance provider untuk mengurangi dampak dari keterbatasanketerbatasan yang dihadapi tersebut.

8. Reference to criteria used

Informasi berikutnya yang harus terdapat dalam independent assurance statement adalah kriteria yang dipergunakan. Dalam konteks ini kriteria yang dipergunakan adalah AA1000APS yang mencakup penilaian inklusivitas, materialitas, dan responsivitas perusahaan dalam menjalankan prinsip-prinsip keberlanjutan perusahaan.

9. Statement of level of assurance

Dalam independent assurance statement harus dicantumkan mengenai level dari audit yang telah dilaksanakan.

10. Findings and conclusions concerning adherence to the AA1000 AccountAbility Principles of Inclusivity, Materiality and Responsiveness (in all instances)

Dalam independent assurance statement harus dicantumkan mengenai 
temuan dan kesimpulan terkait dengan kepatuhan perusahaan terhadap standar AA1000APS yang mencakup kriteria inklusivitas, materialitas, dan responsivitas. Assurance provider harus menjelaskan kesimpulan mengenai kepatuhan manajemen perusahaan terhadap prinsip-prinsip keberlanjutan yang sesuai dengan standar AA1000APS.

11. Findings and conclusions concerning the reliability of specified performance information (for Type 2 assurance only)

Dalam independent assurance statement harus dicantumkan mengenai temuan dan kesimpulan terkait dengan informasi spesifik jika tipe audit yang dilaksanakan adalah tipe 2 .

12. Observations and/or recommendations Assurance provider harus mencantumkan hasil observasi atau rekomendasi yang dapat disampaikan kepada manajemen terkait dengan pelaksanaan audit yang telah dilaksanakan. Rekomendasi yang telah disampaikan oleh assurance provider dapat dipergunakan oleh manajemen perusahaan sebagai dasar dalam perbaikan untuk penyusunan laporan keberlanjutan perusahaan di tahun berikutnya.

13. Notes on competencies and independence of the assurance provider
Dalam independent assurance statement, assurance provider harus mencantumkan mengenai kompetensi dan independensi dari assurance provider.

14. Name of the assurance provider, date and place

Dalam independent assurance statement harus dicantumkan mengenai nama jelas dari assurance provider dan tempat dan tanggal ditandatanganinya independent assurance statement.

Terdapat empat belas informasi minimum yang harus dicantumkan di dalam independent assurance statement. Empat belas informasi minimum yang harus dicantumkan di dalam independent assurance statement telah sesuai dengan ketentuan di dalam standar AA1000AS. Empat belas informasi minimum ini merupakan informasi yang diperlukan untuk meyakinkan pemangku kepentingan bahwa kegiatan audit laporan keberlanjutan perusahaan telah dilaksanakan dengan baik.

Berdasarkan pembahasan yang telah dilakukan maka dapat disusun sebuah model penyusunan dan pelaksanaan program audit laporan keberlanjutan perusahaan. Model penyusunan dan pelaksanaan program audit laporan keberlanjutan perusahaan ini diharapkan dapat diaplikasikan pada saat melakukan audit laporan keberlanjutan perusahaan. Model yang dapat dibentuk terkait dengan audit laporan keberlanjutan perusahaan, yaitu

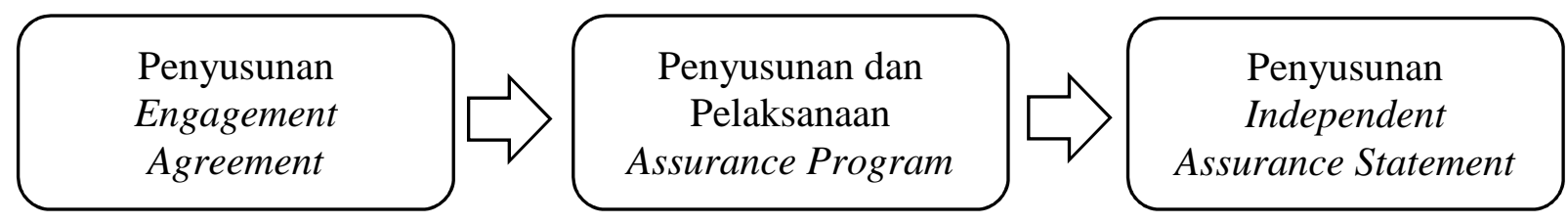

Gambar 1. Analisis penyusunan dan pelaksanaan audit laporan keberlanjutan perusahaan

Analisis ini diawali dengan penyusunan engagement agreement dengan tahapan, yaitu (1) menentukan komposisi tim audit, (2) menentukan ruang lingkup audit, dan (3) menentukan rencana anggaran biaya untuk pelaksanaan kegiatan audit. Tahap berikutnya adalah penyusunan dan pelaksanaan assurance program. Pada tahap ini dilakukan penyusunan assurance program kemudian melaksanakan assurance program yang telah dibuat. Tahapan penyusunan dan pelaksanaan assurance program, yaitu (1) penentuan tingkat materialitas informasi dalam laporan keberlanjutan perusahaan, (2) observasi ke 
lapangan, (3) penentuan bukti-bukti audit, (4) melakukan diskusi kelompok terpumpun dengan pemangku kepentingan perusahaan dan manajemen perusahaan, dan (5) memberikan rekomendasi kepada manajemen perusahaan terkait dengan hasil audit laporan keberlanjutan perusahaan. Tahap terakhir dari model ini adalah penyusunan independent assurance statement yang merupakan pernyataan auditor (assurance provider) terhadap laporan keberlanjutan perusahaan. Dalam independent assurance statement terdapat empat belas informasi minimum yang harus disampaikan oleh assurance provider terkait dengan audit laporan keberlanjutan perusahaan yang telah dilaksanakan. Dengan adanya model audit laporan keberlanjutan ini, maka proses audit akan dapat dilaksanakan dan tentu saja akan menghasilkan kredibilitas yang tinggi pada laporan keberlanjutan yang dipublikasikan oleh manajemen perusahaan. Simnett, et al. (2009) menyatakan bahwa manajemen perusahaan yang cenderung berorientasi pada kredibilitas dan reputasi akan mengupayakan agar laporan keberlanjutan yang dipublikasikan dapat diaudit. Hal ini tentu saja dapat berdampak positif pada proses keberlanjutan aktivitas bisnis perusahaan dan utamanya pada hubungan komunikasi antara manajemen perusahaan dengan pemangku kepentingan perusahaan. Herremans, et al. (2016) berpendapat bahwa setiap pemangku kepentingan perusahaan memerlukan informasi yang spesifik dan disesuaikan dengan kebutuhan dari masing-masing pemangku kepentingan. Proses audit laporan keberlanjutan perusahaan akan memastikan bahwa setiap informasi yang diungkapkan oleh manajemen perusahaan akan memiliki tingkat validitas dan reliabilitas yang tinggi.

\section{SIMPULAN}

Penelitian ini diharapkan dapat memberikan pemahaman mengenai pentingnya audit laporan keberlanjutan perusahaan dan proses audit yang dapat dilakukan. Secara umum model penyusunan dan pelaksanaan audit laporan keberlanjutan perusahaan terdiri dari tiga bagian, yaitu (1) penyusunan engagement agreement, (2) penyusunan dan pelaksanaan assurance program, dan (3) penyusunan independent assurance statement. Independent assurance statement merupakan produk akhir dari proses audit keberlanjutan perusahaan yang merupakan pernyataan assurance provider atau auditor terhadap penyajian informasi manajemen perusahaan pada laporan keberlanjutan perusahaan. Implikasi hasil penelitian ini dalam bidang akademik dapat dipergunakan sebagai materi tambahan pada mata kuliah auditing dan akuntansi sosial dan lingkungan. Mahasiswa akan mendapatkan pemahaman baru bahwa pada dasarnya proses audit tidak hanya pada laporan keuangan saja, tetapi saat ini sudah meluas pada proses pelaporan keberlanjutan perusahaan. Penulis tidak dapat memungkiri bahwa terdapat keterbatasan dalam penelitian ini. Keterbatasan dalam penelitian ini adalah penyusunan kerangka kerja audit masih bersifat konseptual dan belum didasarkan pada kondisi faktual yang ada di perusahaan objek penelitian. Salah satu motivasi penulis menyusun penelitian ini adalah untuk mendukung kegiatan pelaporan keberlanjutan di Indonesia. Kedepannya dapat diteliti mengenai faktor-faktor yang mempengaruhi kualitas audit laporan keberlanjutan perusahaan. Penelitian berikutnya juga dapat membahas bagaimana cara agar pemangku kepentingan perusahaan dapat terlibat secara langsung di dalam proses audit laporan keberlanjutan perusahaan. Penelitian berikutnya dapat pula mengembangkan penelitian Manetti \& Toccafondi (2012) yang meneliti mengenai peran pemangku kepentingan perusahaan dalam proses audit laporan keberlanjutan. Dapat diteliti mengenai peran pemangku kepentingan perusahaan dalam proses audit laporan keberlanjutan dalam konteks perusahaan-perusahaan di Indonesia. Penelitian berikutnya dapat pula mengembangkan penelitian Manetti \& Bellucci (2016) tentang bagaimana manajemen memanfaatkan teknologi dan internet untuk membangun hubungan dengan pemangku kepentingan perusahaan. Penelitian berikutnya dapat melakukan perancangan 
model audit menggunakan desain penelitian Design \& Development (D \& D). Richey \& Klein (2009) menyatakan bahwa desain penelitian D \& D merupakan sebuah sistematika yang berfungsi untuk merancang, mengembangkan, dan mengevaluasi mengenai sebuah produk atau sebuah model baru. Desain penelitian D \& D dipergunakan karena tujuan dari penelitian berikutnya adalah untuk membuat sebuah pengembangan model atau konsep yang baru tentang program audit laporan keberlanjutan perusahaan. Desain penelitian Design \& Development memiliki dua tahap besar, yaitu tahap pertama adalah tahap perancangan atau penyusunan (design) dan tahap kedua adalah tahap pengembangan (development). Penulis berharap kedepannya akan semakin banyak penelitian-penelitian yang membahas mengenai pelaporan keberlanjutan (sustainability reporting) di Indonesia. Hasil-hasil penelitian yang terkait dengan proses pelaporan keberlanjutan perusahaan akan memberikan kita sebuah pemahaman baru dan tentu saja dapat memperkaya pengembangan ilmu akuntansi.

\section{DAFTAR PUSTAKA}

Amran, A., \& Haniffa, R. (2011). Evidence in Development of Sustainability Reporting: A Case of A Developing Country. Business Strategy and the Environment, 20(3), 141-156.

Ballou, B., Heitger, D. L., Landes, C. E., \& Adams, M. (2006). The Future of Corporate Sustainability Reporting. Journal of Accountancy, 202(6), 65-67, 70-74.

Basalamah, A. S., \& Jermias, J. (2005). Social and Environmental Reporting and Auditing in Indonesia. Gadjah Mada International Journal of Business, 7(1), 109-127.

Bradford, M., Earp, J. B., Showalter, D. S., \& Williams, P. F. (2016). Corporate Sustainability Reporting and Stakeholder Concerns: Is There A Disconnect? Accounting Horizons, 31(1), 83-102.

Brown, H. ., Jong, M. ., \& Levy, D. . (2009). Building Institutions Based on
Information Disclosure: Lessons From GRI's Sustainability Reporting. Journal of Cleaner Production, 17(6), 571-580.

Burhan, A. H. N., \& Rahmanti, W. (2012). The Impact of Sustainability Reporting on Company Performance. Journal of Economics, Business \& Accountancy Ventura, 15(2), 257-272.

Guidry, R. P., \& Patten, D. M. (2010). Market Reactions to The First-Time Issuance of Corporate Sustainability Reports: Evidence that Quality Matters. Sustainability Accounting, Management and Policy Journal, 1(1), 33-50.

Hahn, R., \& Kühnen, M. (2013). Determinants of Sustainability Reporting: A Review of Results, Trends, Theory, and Opportunities in An Expanding Field of Research. Journal of Cleaner Production, 59, 5-21.

Herremans, I. ., Nazari, J. ., \& Mahmoudian, F. (2016). Stakeholder Relationships, Engagement, and Sustainability Reporting. Journal of Business Ethics, 138(3), 417-435.

Ioannou, I., \& Serafeim, G. (2017). The Consequences of Mandatory Corporate Sustainability Reporting: Evidence from Four Countries (No. 11-100). https://doi.org/http://dx.doi.org/10.2139/s srn.1799589

Junior, R. M., Best, P. J., \& Cotter, J. (2014). Sustainability Reporting and Assurance: A Historical Analysis on A World-Wide Phenomenon. Journal of Business Ethics, 120(1), 1-11.

Kolk, A. (2004). A Decade of Sustainability Reporting: Developments and Significance. International Journal of Environment and Sustainable Development, 3(1), 51-64.

Kurniawan, P. S. (2017). Profesi Certified Sustainability Reporting Specialist, Pelaporan Keberlanjutan, dan Teori Enterprise (Suatu Tinjauan Mengenai Profesi CSRS dalam Pelaporan Keberlanjutan). Jurnal Ilmu Sosial Dan Humaniora, 6(1), 10-19.

Lozano, R., \& Huisingh, D. (2011). Interlinking Issues and Dimensions in 
Sustainability Reporting. Journal of Cleaner Production, 19(2), 99-107.

Manetti, G., \& Becatti, L. (2009). Assurance Services for Sustainability Reports: Standards and Empirical Evidence. Journal of Business Ethics, 87, 289-298.

Manetti, G., \& Bellucci, M. (2016). The Use of Social Media for Engaging Stakeholders in Sustainability Reporting. Accounting, Auditing \& Accountability Journal, 29(6), 985-1011.

Manetti, G., \& Toccafondi, S. (2012). The Role of Stakeholders in Sustainability Reporting Assurance. Journal of Business Ethics, 107(3), 363-377.

Mock, T. J., Strohm, C., \& Swartz, K. M. (2007). An Examination of Worldwide Assured Sustainability Reporting. Australian Accounting Review, 17(41), 67-77.

Morimoto, R., Ash, J., \& Hope, C. (2005). Corporate Social Responsibility Audit: From Theory to Practice. Journal of Business Ethics, 62(4), 315-325.

Naraduhita, D. C., \& Sawarjuwono, T. (2012). Corporate Social Responsibility: Upaya Memahami Alasan Dibalik Pengungkapan CSR Bidang Pendidikan. Jurnal Akuntansi Dan Auditing, 8(2), 95-108.

National Center for Sustainability Reporting. (2017). Training for Certified Sustainability Reporting Assurer
(CSRA). Malang: NCSR.

O'Dwyer, B., \& Owen, D. L. (2005). Assurance Statement Practice in Environmental, Social and Sustainability Reporting: A Critical Evaluation. The British Accounting Review, 37(2), 205229.

Perego, P. (2009). Causes and Consequences of Choosing Different Assurance Providers: An International Study of Sustainability Reporting. International Journal of Management, 26(3), 412-425.

Richey, R. ., \& Klein, J. . (2009). Design and Development Research. New York: Routledge.

Setiawan, A. (2016). Integrated Reporting: Are Indonesian Companies Ready to Do It? Asian Journal of Acconting Research, 1(2), 62-70.

Simnett, R., Vanstraelen, A., \& Chua, W. F. (2009). Assurance on Sustainability Reports: An International Comparison. Accounting Review, 84(3), 937-967.

Srivastava, R. P., Rao, S. S., \& Mock, T. J. (2013). Planning and Evaluation of Assurance Services for Sustainability Reporting: An Evidential Reasoning Approach. Journal of Information Systems, 27(2), 107-126.

Wallage, P. (2000). Assurance on Sustainability Reporting: An Auditor's View. Auditing: A Journal of Practice \& Theory, 19(1), 53-65. 